УДК 539.16.04+51-76: 612.119

Р. В. Бойко, Д. І. Білько, І. 3. Руссу, Н. М. Білько

Національний університет «Києво-Могилянська академія», вул. Г. Сковороди, 2, Київ, 04070

ПОРІВНЯЛЬНИЙ МАТЕМАТИЧНИЙ АНАЛІЗ КОЛОНІЕУТВОРЮЮЧОЇ ЗДАТНОСТІ КІСТКОВОГО МОЗКУ

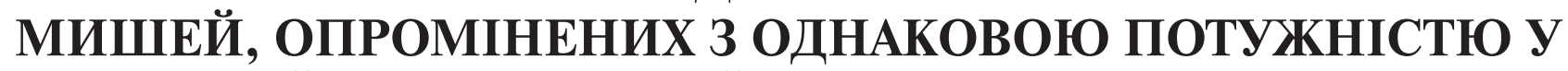
ЛЕТАЛЬНІЙ І НЕЛЕТАЛЬНІЙ ДОЗАХ

Мета: проведення порівняльного аналізу характеристик процесу функціонування популяції колонієутворюючих одиниць кісткового мозку мишей після пролонгованого їх опромінення у летальній і нелетальній дозах 3 однаковою потужністю доз за допомогою математичної моделі.

Матеріали і методи. Поставлена задача розв'язується за допомогою математичної моделі зміни чисельності колонієутворюючих одиниць кісткового мозку після неперервного опромінення, описаної в попередніх роботах, 3 використанням експериментальних результатів робіт К. С. Черткова $(1972,1973)$. Математична модель побудована на основі схеми кровотворення, запропонованої Й. Л. Чертковим $(1984,1991)$.

Результати та висновки. За допомогою оригінальної математичної моделі, нової схеми кровотворення Й. Л. Черткова (1991) з використанням експериментальних результатів впливу $\gamma$-опромінення в дозах 4 Гр та 8 Гр 3 потужністю 0,0028 Гр/хв на чисельність колонієутворюючих одиниць кісткового мозку мишей, а також експериментальних даних щодо процесів відновлення їхньої чисельності, одержаних з літературних джерел, визначено параметри, що характеризують реакцію кровотворної системи на різних етапах процесів відновлення колонієутворюючих одиниць кісткового мозку після припинення дії іонізуючої радіації, та проведено порівняльний аналіз отриманих результатів.

Ключові слова: іонізуюча радіація, летальна та нелетальна дози, кістковий мозок, функціональні властивості, математичне моделювання.

Проблеми радіаційної медицини та радіобіології. 2020. Вип. 25. С. 300-308. doi: 10.33145/2304-8336-2020-25-300-308

Білько Надія Михайлівна, e-mail: nadia.bilko@gmail.com 


\section{COMPARATIVE MATHEMATICAL ANALYSIS OF COLONY- FORMING ABILITYOF THE BONE MARROW OF MICE LETHALLY AND NON-LETHALLY IRRADIATED WITH EQUAL DOSE RATE INTENSITY}

Objective. To perform comparative analysis of the characteristics of population functioning process of mice bone marrow colony-forming units after their prolonged irradiation in lethal and non-lethal doses with equal dose rate intensity with the aid of mathematical model.

Materials and methods. Assigned task is solved by means of mathematical model of alterations in the number of bone marrow colony-forming units after continuous irradiation, described in previous works, with the use of experimental results of K. S. Chertkov works $(1972,1973)$. Mathematical model is developed basing on the hematopoiesis scheme introduced by I. L. Chertkov (1984, 1991).

Results and conclusions. By applying original mathematical model, new scheme of hematopoiesis [6], with the use of experimental results of $\gamma$-irradiation influence in the doses of $4 \mathrm{~Gy}$ and $8 \mathrm{~Gy}$ with the dose rate intensity of $0.0028 \mathrm{~Gy} / \mathrm{min}$ on the number of mice bone marrow colony-forming units, as well as experimental data concerning the processes of their number recovery, obtained from literature references, we determined the parameters, which characterize hematopoietic system reaction on the different stages of recovery processes of mice bone marrow colony-forming units after the termination of ionizing radiation action; comparative analysis of obtained results was performed.

Key words: ionizing radiation, lethal and non-lethal doses, bone marrow, functional properties, mathematical modelling.

Problems of Radiation Medicine and Radiobiology. 2020;25:300-308. doi: 10.33145/2304-8336-2020-25-300-308

\section{ВСТУП}

Наслідки опромінення організму, як відомо, визначаються станом кровотворної тканини, що є однією 3 критичних систем організму ссавців при радіаційному впливі. У зв'язку з цим актуальним є вивчення закономірностей ураження і компенсації кровотворної системи.

Колонієутворюючі одиниці (КУО), що належать до пулу стовбурових кровотворних клітин, є провідним фактором у розвитку процесів відновлення гемопоезу в опроміненому організмі, а отже, і в наслідках променевого ураження з переважанням кістково-мозкового синдрому. Закономірності відновлення популяції КУО кісткового мозку (КМ) мишей після опромінення значною мірою визначають наступний процес відновлення гемопоетичної системи в цілому.

Метод кількісного визначення колонієутворюючих одиниць надав нові можливості для вивчення стовбурового пулу кровотворної тканини.

Математична модель побудована на основі нової схеми кровотворення, запропонованої Й. Л. Чертко-

\section{INTRODUCTION}

The effects of irradiation of the body, as it is known, are determined by the state of hematopoietic tissue, which is one of the critical systems of the mammalian organism under the radiation influence. In this regard, it is important to study the patterns of damage and compensation of the hematopoietic system.

Colony-forming units (CFU) which belong to the pool of hematopoietic stem cells are a leading factor in the development of hematopoietic recovery in the irradiated organism, and hence in the consequences of radiation damage with a predominance of bone marrow syndrome. Patterns of the recovery of colony-forming units' population of mice bone marrow (BM) after the irradiation to a large extent determine the further process of recovery of the whole hematopoietic system.

The method of quantitative determination of colony-forming units provided new opportunities for studying the stem pool of hematopoietic tissue.

The mathematical model is based on a new scheme of hematopoiesis proposed by I. L. Chertkov $[1,2]$.

Nadiia M. Bilko,e-mail: nadia.bilko@gmail.com 
вим $[1,2]$. Згідно з цією схемою, кровотворення організму протягом усього життя підтримується закладеними в онтогенезі примітивними стовбуровими клітинами, які поступово дозрівають і послідовно, одна за одною, поповнюють популяцію КУО КМ та беруть участь у процесі гемопоезу.

За теорією Й. Л. Черткова $[1,2]$ потенціал стовбурових клітин не є нескінченним, він виснажується, особливо в результаті стресів (наприклад, опромінення). Стовбурові клітини закладаються в ембріогенезі, дозрівають і колонізують «ніші» в організмі новонародженої дитини, які і є джерелами гемопоетичних стовбурових клітин протягом життя, у першу чергу, це кістковий мозок.

\section{МЕТА ДОСЛІДЖЕННЯ}

Метою даної роботи є проведення порівняльного аналізу характеристик процесу функціонування популяції КУО КМ мишей після пролонгованого їх опромінення у летальній і нелетальній дозах з однаковою потужністю доз за допомогою математичної моделі.

\section{МАТЕРІАЛИ І МЕТОДИ}

Поставлена задача розв'язується за допомогою математичної моделі зміни чисельності КУО КМ після неперервного опромінення, описаної в роботах [3, 4], з використанням експериментальних результатів робіт К. С. Черткова $[5,6]$.

Як представлено у статтях К. С. Черткова, дослідження проводили на мишах-гібридах F1 (CBA x C57Bl). Дослідники опромінювали мишей-донорів у дозах 400 рад (4 Гр) та 800 рад (8 Гр) $\gamma$-променями ${ }^{137} \mathrm{Cs}$ iз потужністю дози 0,0028 Гр/хв.

Для визначення числа клітин промивали ліву стегнову кістку мишей 2-4 мл $5 \%$ оцтової кислоти і підраховували кількість ядровмісних клітин. Для встановлення кількості колоній, які формуватимуться в селезінці тварин-реципієнтів, стерильно вимивали клітини з правої стегнової кістки тварин-донорів у середовищі 199, підраховували їхню кількість і вводили у хвостову вену летально опроміненої тварини-реципієнта. Для цього опромінених у різних дозах тварин-донорів забивали у різні терміни після закінчення впливу радіації (від 0,5 год до 30 діб).

Опромінення експериментальних тварин у летальних дозах, що викликають гостру променеву хворобу (800 рад), і тих, що є сублетальними (400 рад), можна підрозділити на короткочасне, що вимірюється секундами та хвилинами, і пролонговане, що триває години чи доби. Автори публікацій К. С. Чертков (1973),
According to this scheme, the hematopoiesis of the organism throughout life is supported by primitive stem cells deposited in ontogenesis, which gradually mature and consistently, one after another, replenish the population of BM CFU and participate in the process of hematopoiesis.

According to the theory of I. L. Chertkov [1, 2] the potential of stem cells is not infinite, it is depleted, especially as a result of the stresses (for example, irradiation). Stem cells are deposited in embryogenesis, maturate and colonize 'niches' in the organism of new-born child, which are the sources of hematopoietic stem cells during the life, first of all, the bone marrow.

\section{OBJECTIVE}

The objective of investigation was to perform comparative analysis of the characteristics of population functioning process of mice bone marrow colony-forming units after their prolonged irradiation in lethal and non-lethal doses with equal dose rate intensity with the aid of mathematical model.

\section{MATERIALS AND METHODS}

The assigned task is solved by means of mathematical model of the alterations in BM CFU number after the continuous irradiation, described in works [3, 4], with the use of experimental results of K. S. Chertkov works $[5,6]$.

As presented in the articles of K.S. Chertkov, the investigations were performed on hybrid mice F1 $(\mathrm{CBA} \times \mathrm{C} 57 \mathrm{Bl})$. The researchers irradiated donor mice at doses of $400 \mathrm{rad}(4 \mathrm{~Gy})$ and $800 \mathrm{rad}(8 \mathrm{~Gy})$ with ${ }^{137} \mathrm{Cs} \gamma$-rays with a dose rate of $0.0028 \mathrm{~Gy} / \mathrm{min}$.

To determine the number of cells, the left femur of mice was washed with 2-4 ml of $5 \%$ acetic acid and the number of nucleated cells was counted. To determine the number of colonies, which will form in the spleen of recipient animals, cells were aseptically washed from the right femur of donor animals with 199 medium, counted, and injected into the tail vein of lethally irradiated recipient animal. To do this, donor animals irradiated in different doses were killed at different times after the termination of radiation exposure (from 0.5 hours to 30 days).

Irradiation of experimental animals in lethal doses, which cause acute radiation sickness ( $800 \mathrm{rad}$ ), and those which are sublethal (400 rad), can be divided into short-term, measured in seconds and minutes, and prolonged, ongoing years or days. The authors of the publications K.S. Chertkov 
К. С. Чертков і С. П. Храмченкова (1972) прослідкували кінетику ураження і відновлення у пролонговано опромінених тварин; на основі їх даних за допомогою математичної моделі проведено порівняльний аналіз процесу функціонування популяції колонієутворюючих одиниць кісткового мозку мишей при летальній та нелетальній дозі опромінення з однаковою малою потужністю $(0,28$ рад/хв) $[5,6]$.

Дані щодо кінетики зміни колонієутворення у розрахунку на стегнову кістку мишей-донорів представлені в табл. 1 і 2.

Розрахунки, проведені з урахуванням зміни числа ядровмісних клітин показали, що у стегновій кістці миші, опроміненої пролонговано у дозі 400 рад
(1973), K.S. Chertkov and S.P. Khramchenkova (1972) investigated the kinetics of damage and recovery in protractedly irradiated animals; based on their data and using a mathematical model the comparative analysis was performed concerning the functioning of CFU population of mice BM at lethal and non-lethal doses with the same low dose rate $(0.28 \mathrm{rad} / \mathrm{min}$.$) [5, 6].$

Data concerning the kinetics of changes in colony forming per femur of donor mice are presented in table 1 and 2 .

Calculations performed taking into account the change in the number of nucleated cells showed that $2.3 \%$ of the original amount of cells retain their

\section{Таблиця 1}

Кінетика колонієутворюючих клітин кісткового мозку мишей після пролонгованого опромінення в дозі 400 рад [6]

Table 1

Kinetics of colony-forming bone marrow cells of mice after prolonged irradiation with the dose of $400 \mathrm{rad}$ [6]

\begin{tabular}{|c|c|c|c|}
\hline \multirow{2}{*}{$\begin{array}{c}\text { Доба після початку } \\
\text { опромінення } \\
\text { Days after the beginning } \\
\text { of irradiation }\end{array}$} & \multirow{2}{*}{$\begin{array}{c}\text { Кількість } \\
\text { тварин-реципієнтів } \\
\text { Number of } \\
\text { recipient animals }\end{array}$} & \multicolumn{2}{|c|}{$\begin{array}{c}\text { Кількість КУО в розрахунку на стегнову кістку } \\
\text { Number of CFU per femur }\end{array}$} \\
\hline & & $\begin{array}{l}\text { абсолютна кількість } \\
\text { absolute number }\end{array}$ & $\begin{array}{l}\text { довірчий інтервал } \\
\text { confidence interval }\end{array}$ \\
\hline 1 & 16 & 131 & $(102-159)$ \\
\hline 2 & 8 & 230 & (207-253) \\
\hline 3 & 12 & 366 & $(255-473)$ \\
\hline 6 & 5 & 662 & (431-894) \\
\hline 8 & 5 & 873 & $(310-1436)$ \\
\hline 13 & 3 & 1120 & $(624-1616)$ \\
\hline 22 & 5 & 2094 & (1795-2394) \\
\hline
\end{tabular}

\section{Таблиця 2}

Кінетика колонієутворюючих клітин кісткового мозку мишей після пролонгованого опромінення в дозі 800 рад [5]

\section{Table 2}

Kinetics of colony-forming bone marrow cells of mice after prolonged irradiation with the dose of $800 \mathrm{rad}$ [5]

\begin{tabular}{|c|c|c|c|c|}
\hline \multirow{2}{*}{$\begin{array}{c}\text { Доба після початку } \\
\text { опромінення } \\
\text { Days after the beginning } \\
\text { of irradiation }\end{array}$} & \multicolumn{2}{|c|}{$\begin{array}{l}\text { Кількість тварин } \\
\text { Number of animals }\end{array}$} & \multicolumn{2}{|c|}{$\begin{array}{c}\text { Кількість КУО в розрахунку на стегнову кістку } \\
\text { Number of CFU per femur }\end{array}$} \\
\hline & $\begin{array}{c}\text { донори } \\
\text { donors }\end{array}$ & $\begin{array}{l}\text { реципієнти } \\
\text { recipients }\end{array}$ & $\begin{array}{l}\text { абсолютна кількість } \\
\text { absolute number }\end{array}$ & $\begin{array}{l}\text { довірчий інтервал } \\
\text { confidence interval }\end{array}$ \\
\hline 2 & 5 & 5 & 5,2 & $(1,5-8,9)$ \\
\hline 3 & 8 & 16 & 20,1 & $(16,3-23,8)$ \\
\hline 4 & 8 & 17 & 30,9 & $(25,8-35,7)$ \\
\hline 7 & 8 & 16 & 144,5 & $(117-172)$ \\
\hline 9 & 5 & 8 & 267 & (202-332) \\
\hline 11 & 8 & 9 & 1254 & $(980-1509)$ \\
\hline 13 & 8 & 9 & 1889 & (1524-2244) \\
\hline 16 & 5 & 9 & 2134 & (1745-2530) \\
\hline 19 & 5 & 11 & 4774 & (4400-5148) \\
\hline 23 & 5 & 5 & 4749 & (3360-6137) \\
\hline 30 & 5 & 3 & 5507 & (3806-7214) \\
\hline
\end{tabular}


(4 Гр), колонієутворюючу здатність зберігають $2,3 \%$ вихідної кількості клітин. Далі, як видно з таблиць 1 і 2, число колонієутворюючих клітин у кістковому мозку збільшується протягом всього періоду спостереження.

Автори показали, що в результаті пролонгованого опромінення не розвивається стан тотального пригнічення процесу проліферації клітин; частина колонієутворюючих клітин зберегає властивий їм постійний ритм проліферації. Саме неперервність процесу накопичення колонієутворюючих клітин може забезпечити тваринам, опроміненим пролонговано, певний виграш у часі в період відновлення. Незважаючи на те, що з моменту експериментального доведення закономірностей відновлення кровотворної функції після пролонгованого опромінення при низькій потужності пройшло майже пів століття, результати проведених досліджень не втратили своєї актуальності і переконливості.

Головна особливість, притаманна пролонгованиму впливу, полягає в тому, як вказують автори, що при незначній потужності (нижче 1 рад/хв), частина клітин не втрачає здатності до проліферації. Збережена кількість стовбурових клітин є достатньою для створення надійного плацдарму для інтенсивного гемопоезу у тварин, чим, найімовірніше, і пояснюється синхронність у відновленні кровотворення.

Автори висувають припущення про те, що причину підвищення резистентності до променевого ураження у тварин слід розглядати як відповідь на пролонговане опромінення з незначною потужністю дози.

\section{РЕЗУЛЬТАТИ ТА ОБГОВОРЕННЯ}

Отже, згідно з роботами [3, 4], рівняння, що описує зміни відносної чисельності КУО КМ після припинення опромінення, матиме вигляд: colony-forming ability in the femur of a mouse irradiated protractedly in the dose of $400 \mathrm{rad}$ (4 Gy). Further, as can be seen from tables 1 and 2, the number of colony-forming cells in the bone marrow increases throughout the observation period.

The authors showed that as a result of prolonged irradiation a state of total inhibition of the process of cell proliferation is not developed; part of the colony-forming cells retains their inherent constant rhythm of proliferation. It is the continuity of the process of colony-forming cells accumulation that can provide the animals with prolonged exposure a certain gain in time during the recovery period. Despite the fact that almost half a century has passed since the experimental proof of the restoration pattern of hematopoietic function after prolonged irradiation with low dose rate, the results of the performed research have not lost their relevance and persuasiveness.

The main feature which is inherent to prolonged exposure is, as the authors indicate, that at low dose rate (below $1 \mathrm{rad} / \mathrm{min}$.), some cells do not lose the ability to proliferate. The preserved number of stem cells is sufficient to create a reliable base for intensive hematopoiesis in animals, which, most likely, explains the synchronicity in the restoration of hematopoiesis.

The authors suggest that the cause of increased resistance to radiation damage in animals should be considered as a response to prolonged exposure at low dose rates.

\section{RESULTS AND DISCUSSION}

So, according to the works [3, 4], equation, which describes alterations in relative number of BM CFU after the termination of irradiation, will be written as:

$$
\frac{d M(t)}{d t}=\frac{m_{0}}{\tau_{0} C_{K}}+\frac{p}{\tau} M(t)-\frac{d}{\tau} M(t)
$$

де $M_{1}(t)=\frac{N(t)}{C_{K}}-$ відносна чисельність КУО КМ

через проміжок часу $t$ після припинення опромінення;

$N(t)$ - чисельність КУО КМ через проміжок часу $t$ після припинення опромінення;

$C_{K}$ - чисельність КУО КМ у нормі;

$\frac{m_{0}}{\tau_{0} C_{K}}-$ відносна швидкість надходження КУО до КМ;

$\tau_{0}$ - тривалість проміжку часу, через який клітини надходять до популяції КУО; where $M_{1}(t)=\frac{N(t)}{C_{K}} \quad-$ relative number of BM

CFU in the interval of time $t$ after the termination of irradiation

$N(t)$ - number of BM CFU in the interval of time $t$ after the termination of irradiation;

$C_{K}$ - number of BM CFU in normal conditions;

$\frac{m_{0}}{\tau_{0} C_{K}}-$ relative incoming rate of CFU to $\mathrm{BM}$;

$\tau_{0}-$ duration of the time interval, in which cells come to $\mathrm{CFU}$ population; 
$m_{0}-$ кількість джерел, з яких надходять КУО до КМ; $p$ - відсоток клітин, які при поділі поповнюють популяцію КУО;

$d$ - відсоток клітин, які при поділі поповнюють популяцію комітованих попередників кровотворення;

$\tau$ - середня тривалість клітинного циклу КУО КМ.

Розв'язок рівняння (1) на проміжках часу, де параметри відновлення популяції КУО КМ $\frac{m_{0}}{\tau_{0} C_{K}}$, $p, d, \tau$ незмінні, матиме такий вигляд:

$$
M(t)=\frac{m_{0}}{\tau_{0} C_{K}(-\lambda)}+e^{\lambda t}\left(M\left(t_{0}\right)+\frac{m_{0}}{\tau_{0} C_{K}}\right)
$$

де $\lambda=\frac{p-d}{\tau}, M\left(t_{0}\right)-$ відносна чисельність КУО КМ на початку спостереження $t_{0}$;

за умови $\lambda<0$ величину $S=\frac{m_{0}}{\tau_{0} C_{K}(-\lambda)}$ називатимемо відносним рівнем стабілізації КУО КМ, коли $t \rightarrow \infty$ при незмінних параметрах функціонування популяції КУО КМ.

Результати зміни відносної чисельності КУО КМ стегнової кістки мишей F1 (CBA x C57B1) після пролонгованого опромінення у дозах 4 Гр та 8 Гр (табл. 3 і 4) отримані з експериментальних резуль- $m_{0}-$ number of sources, from which CFU come to BM; $p$ - percent of the cells, which after the division replenish the population of CFU;

$d$-percent of the cells, which after the division replenish the population of committed hematopoietic progenitors;

$\tau-$ the average duration of BM CFU cell cycle.

Solution to equation (1) in the intervals of time, where parameters of BM CFU population recovery $\frac{m_{0}}{\tau_{0} C_{K}}$, where $\lambda=\frac{p-d}{\tau}, M\left(t_{0}\right)-$ relative number of $\mathrm{BM} \mathrm{CFU}$ at the beginning of observation $t_{0}$;

upon condition $\lambda<0$ the $S=\frac{m_{0}}{\tau_{0} C_{K}(-\lambda)} \quad$ value we will call the relative level of $\mathrm{BM} C F U$ stabilization, when $t \rightarrow \infty$ in case of constant parameters of BM CFU population functioning.

Results of the alterations in relative number of femur BM CFU of mice F1 (CBA x C57Bl) after prolonged irradiation in the doses of 4 Gy and 8 Gy (Table 3 and 4) are obtained from the experimental results of works

\section{Таблиця 3}

Параметри математичної моделі, що описує зміну відносної чисельності куо кМ мишей після пролонгованого опромінення у дозі 4 Гр (сублетальна доза)

\section{Table 3}

Parameters of mathematical model, which describes the alteration of relative number of mice BM CFU after prolonged irradiation in the dose of $4 \mathrm{~Gy}$ (sub-lethal dose)

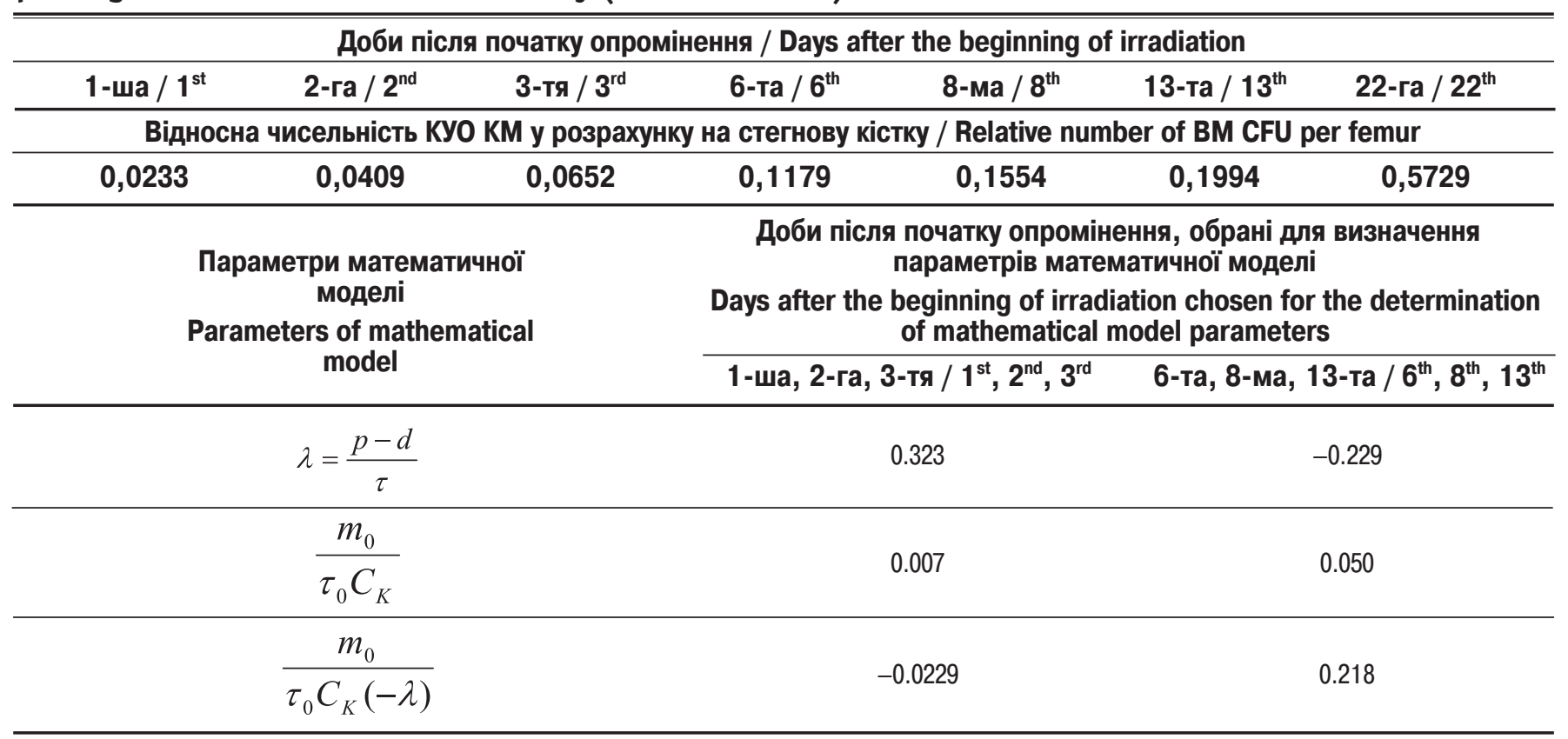




\section{Таблиця 4}

Параметри математичної моделі, що описує зміну відносної чисельності куо кМ мишей після пролонгованого опромінення у дозі 8 Гр (летальна доза)

\section{Table 4}

Parameters of mathematical model, which describes the alteration of relative number of mice BM CFU after prolonged irradiation in the dose of $8 \mathrm{~Gy}$ (lethal dose)

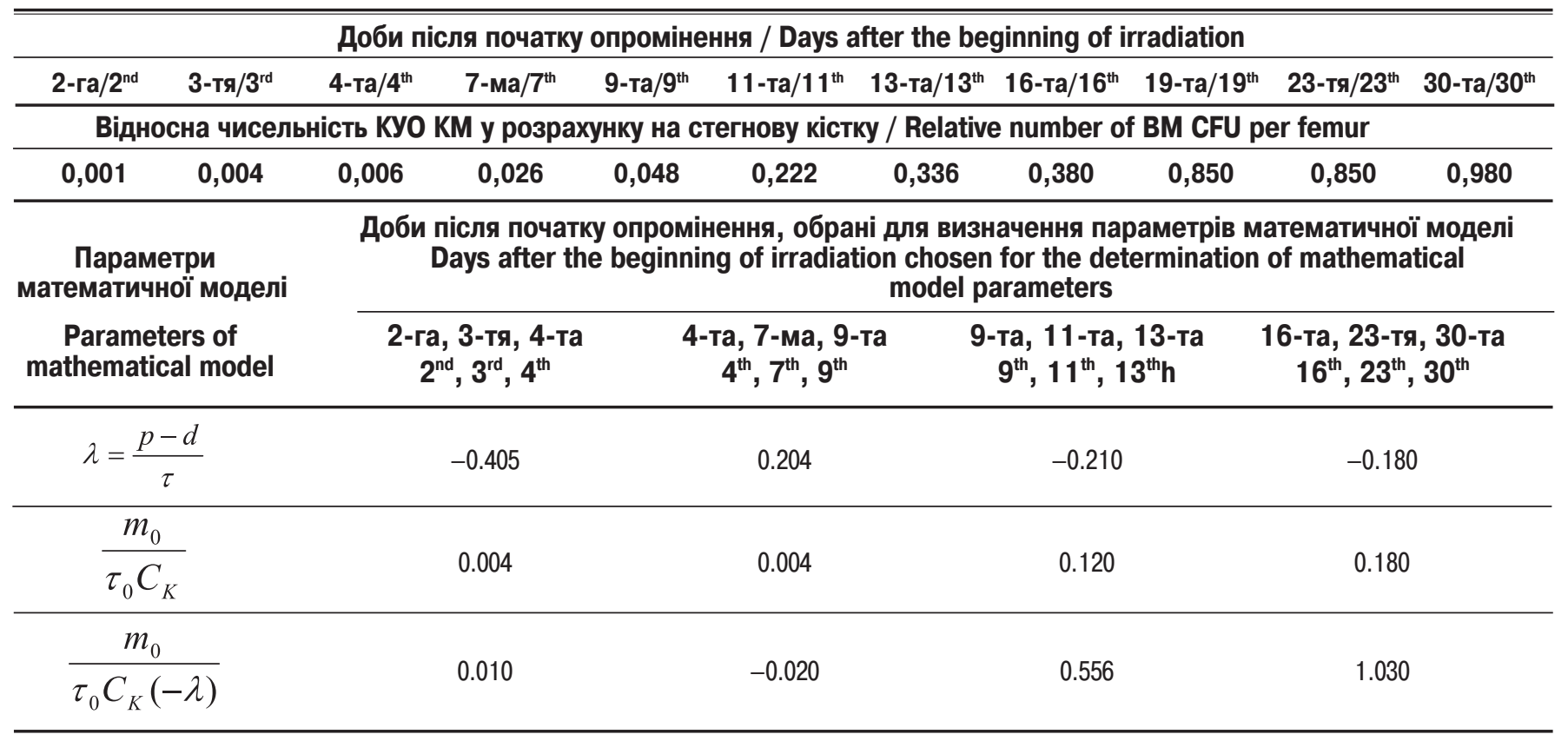

татів робіт $[5,6]$ з урахуванням того факту, що $C_{K}-$ чисельність КУО КМ стегнової кістки у нормі становить 5616 (5382-5850) клітин [5].

Проілюструємо метод обчислення параметрів математичної моделі, що описує зростання відносної чисельності КУО КМ у перші доби після припинення пролонгованого опромінення у дозі 4 Гр.

3 формули (2), що описує зміну відносної чисельності КУО КМ $M(t)$ від початку спостереження $t_{0}=1$ до терміну $t$, випливає

$[5,6]$ taking into account the fact that $C_{K}-$ number of femur BM CFU is equal to $5616(5382-5850)$ cells in normal conditions [5].

We will illustrate the method for the estimation of mathematical model parameters, which describes the increase of relative number of BM CFU in the first days after the termination of prolonged irradiation in the dose of $4 \mathrm{~Gy}$.

From the formula (2), which describes the alteration in the relative number of BM CFU $M(t)$ from the beginning of observation $t_{0}=1$ to the period of time $t$, it follows that

$$
\begin{aligned}
& M(1)-M(2)=(\operatorname{M}(1)-S)\left(1-e^{\lambda}\right), \\
& M(2)-M(3)=(\operatorname{M}(1)-S)\left(e^{\lambda}-e^{2 \lambda}\right),
\end{aligned}
$$

де $S=\frac{m_{0}}{\tau_{0} C_{K}(-\lambda)}$.

Враховуючи значення $M(1), M(2), M(3)$ із таблиці 3, отримаємо

$$
\frac{M(2)-M(3)}{M(1)-M(2),}=e^{\lambda}=1,3806 . \text { Отже, } \lambda \approx 0,323 .
$$

Із рівності (4) знаходимо where $S=\frac{m_{0}}{\tau_{0} C_{K}(-\lambda)}$.

Taking into account the value of $M(1), M(2), M(3)$ from the Table 3, we will obtain

$$
\frac{M(2)-M(3)}{M(1)-M(2),}=e^{\lambda}=1,3806 \text {. Thus, } \lambda \approx 0,323 .
$$

From the equation (4) we will find

$$
S=\frac{m_{0}}{\tau_{0} C_{K}(-\lambda)}=M(1)-\frac{M(2)-M(3)}{e^{\lambda}-e^{2 \lambda}} \approx-0,0229 .
$$




$$
\text { Тоді } \frac{m_{0}}{\tau_{0} C_{K}}=0,007 \text {. }
$$

Аналіз результатів, наведених у таблицях 3 і 4, свідчить, шо основними показниками, які визначають рівень впливу опромінення на систему кровотворення, є чисельність КУО КМ та процес іï відновлення після припинення опромінення.

У перший день після припинення сублетального опромінення у дозі 4 Гр відносна чисельність КУО КМ становить 0,02, відносна швидкість надходження КУО до КМ дорівнює 0,007; вона не змінюється протягом 3 діб, а на початок 6-ї доби зростає у 7 разів.

У перший день після припинення летального опромінення у дозі 8 Гр відносна чисельність КУО КМ становить 0,001 , відносна швидкість надходження КУО до КМ рівна 0,004; вона не змінюється протягом наступних 7 діб, а на початок 9-ї доби зростає у 30 разів.

Визначені параметри процесів відновлення КУО КМ після сублетального і летального опромінення дають підставу вважати, що саме процес відновлення КУО КМ після летального опромінення з такими параметрами протягом перших 9 діб став причиною затримки зростання чисельності КУО КМ i, як наслідок, причиною загибелі частини мишей в експерименті.

\section{ВИСНОВКИ}

Отримані результати дозволяють здійснити порівняльний аналіз параметрів, які характеризують процеси відновлення КУО КМ мишей, опромінених у летальній і сублетальній дозах, за допомогою математичної моделі,та сформулювати висновок щодо причин загибелі частини мишей після опромінення у летальній дозі.

Встановлення наслідків дії іонізуючої радіації в залежності від іiі дози і потужності при пролонгованому опроміненні доцільно здійснювати не тільки в теоретичному, а і в практичному відношенні, оскільки останнє строго описується математично, а тому може слугувати надійним тестом у радіобіологічних дослідженнях.

\section{СПИСОК ВИКОРИСТАНИХ ДЖЕРЕЛ}

1. Чертков И. Л., Гуревич О. И. Стволовая кроветворная клетка и ее микроокружение. М. : Медицина, 1984. 240 с.

2. Чертков И. Л., Дерюгина Е. И., Левир Р. Д., Абрахим Н. Г. Стволовая кроветворная клетка: дифференцировочный и пролиферативный потенциал. Успехи современной биологии. 1991. Т. 111, вып. 6. С. 905-922.

$$
\text { Then } \frac{m_{0}}{\tau_{0} C_{K}}=0,007
$$

Analysis of the results presented in Tables 3 and 4 shows that the main indices, which determine the level of irradiation influence on hematopoietic system, are BM CFU number and the process of its recovery after the termination of irradiation.

On the first day after the termination of sub-lethal irradiation in the dose of $4 \mathrm{~Gy}$ the relative number of $\mathrm{BM} C F U$ is equal to 0.02 , the relative incoming rate of $\mathrm{CFU}$ to $\mathrm{BM}$ is equal to 0.007 ; it does not change during 3 days and at the beginning of the $6^{\text {th }}$ day increases 7 times.

On the first day after the termination of lethal irradiation in the dose of $8 \mathrm{~Gy}$ the relative number of $\mathrm{BM} \mathrm{CFU}$ is equal to 0.001 , the relative incoming rate of CFU to $\mathrm{BM}$ is equal to 0.004 ; it does not change during next 7 days and at the beginning of the $9^{\text {th }}$ day increases 30 times.

Determined parameters of the processes of BM CFU recovery after sub-lethal and lethal irradiation give the basis to conclude, that the process of $\mathrm{BM}$ CFU recovery itself after the lethal irradiation with such parameters during the first 9 days became the reason for the delay of the increase of $\mathrm{BM} C F U$ number and, as a result, the reason of the death of some mice in the experiment.

\section{CONCLUSIONS}

Obtained results allow performing the comparative analysis of the parameters which characterize the processes of BM CFU recovery in mice irradiated in lethal and sub-lethal doses, with the aid of mathematical model, as well as to formulate the conclusion concerning the reasons for the death of some mice after the irradiation in lethal dose.

Establishing the effects of ionizing radiation depending on its dose and rate under prolonged irradiation should be carried out not only with theoretical but also with practical approach, as the latter is strictly described mathematically, and therefore can serve as a reliable test in radiobiological research.

\section{REFERENCES}

1. Chertkov I. L., Gurevich O. I. [Stem hematopoietic cell and its microenvironment]. Moscow: Meditsina; 1984. 240 p. Russian.

2. Chertkov I. L., Derugina E. I., Levir R. D., Abrakhim N. G. [Stem hematopoietic cell: differentiation and proliferative potential]. Uspekhi sovremennoi biologii. 1991;111(6):905-922. Russian. 


\section{ЕКСПЕРИМЕНТАЛЬНІ}

ДОСЛІДЖЕННЯ

3. Бойко Р. В., Білько Д. І., Руссу І. 3., Білько Н. М. Математичний аналіз функціональних властивостей кісткового мозку мишей у процесі тривалого зовнішнього гамма-опромінення та після його припинення. Ядерна фізика та енергетика. 2016. Т. 17, № 2. С. $176-179$.

4. Бойко Р. В., Білько Д. І., Руссу І. З., Білько Н. М. Математичний аналіз зміни функціональних властивостей кісткового мозку мишей у процесі тривалого зовнішнього опромінення з різною потужністю дози. Ядерна фізика та енергетика. 2015. Т. 16, № 4. С. 389-397.

5. Чертков К. С. Влияние мощности дозы облучения на процессы поражения и восстановления колониеобразующих клеток костного мозга. Радиобиология. 1973. Т. 13, вып. 3. С. 368-372.

6. Чертков К. С., Храмченкова С. П. Сопоставление действий кратковременного и пролонгированного облучений в равновеликих несмертельных дозах на кроветворение мышей. Радиобиология. 1972. Т. 12, вып. 1. С. $77-84$.

\section{ІНФОРМАЦІЯ ПРО АВТОРІВ}

Бойко Роман Володимирович, доктор фізико-математичних наук, професор, провідний науковий співробітник Центру молекулярних і клітинних досліджень Національного університету «Києво-Могилянська академія», м. Київ

Білько Денис Іванович, кандидат біологічних наук, доцент, доцент кафедри лабораторної діагностики біологічних систем Національного університету «Києво-Могилянська академія», м. Київ

Руссу Ірина Зіновіївна, кандидат біологічних наук, доцент кафедри лабораторної діагностики біологічних систем Національного університету «Києво-Могилянська академія», м. Київ

Білько Надія Михайлівна, доктор медичних наук, професор, завідувач кафедри лабораторної діагностики біологічних систем Національного університету «Києво-Могилянська академія», м. Київ
3. Boiko RV, Bilko DI, Russu IZ, Bilko NM. [Mathematical analysis of the functional properties of the murine bone marrow in the process of prolonged external gamma-irradiation and after its termination]. Nuclear Physics and Atomic Energy. 2016;17(2): 176179. Ukrainian.

4. Boiko RV, Bilko DI, Russu IZ, Bilko NM. [Mathematical analysis of functional properties alteration of mice bone marrow during protracted external irradiation with different dose rate intensity]. Nuclear Physics and Atomic Energy. 2015;16(4):389-397. Ukrainian.

5. Chertkov KS. [The influence of radiation intensity dose on the processes of damage and recovery of bone marrow colony-forming cells]. Radiobiologiya. 1973;13(3):368-372. Russian.

6. Chertkov KS., Khramchenkova S. P. [Comparison of the actions of short-term and prolonged irradiations in equal non-lethal doses on mice hematopoiesis]. Radiobiologiya. 1972;12(1):77-84. Russian.

\section{INFORMATION ABOUT AUTHORS}

Roman V. Boiko, Doctor of Physical and Mathematical Sciences, Professor, Leading Researcher of the Center for Molecular and Cellular Research, National University of Kyiv-Mohyla Academy, Kyiv, Ukraine

Denys I. Bilko, Candidate of Biological Sciences, Associate Professor, Associate Professor of the Department of Laboratory Diagnostics of Biological Systems, National University of Kyiv-Mohyla Academy, Kyiv, Ukraine

Iryna Z. Russu, Candidate of Biological Sciences, Associate Professor of the Department of Laboratory Diagnostics of Biological Systems, National University of Kyiv-Mohyla Academy, Kyiv, Ukraine

Nadiia M. Bilko, Doctor of Biological Sciences, Professor, Head of the Department of Laboratory Diagnostics of Biological Systems, National University of Kyiv-Mohyla Academy, Kyiv, Ukraine 